\title{
Multiclass MSPD Method for Pesticide Determination in Dehydrated Hyptis pectinata (Sambacaitá) Medicinal Plant by GC-MS
}

\author{
Adriano Aquino, Michel R. R. Souza, Samia T. A. Maciel, Marcelo da Rosa Alexandre \\ and Sandro Navickiene*
}

\author{
Departamento de Química, Universidade Federal de Sergipe, Av. Marechal Rondon s/n, \\ 49100-000 São Cristóvão-SE, Brazil
}

\begin{abstract}
Um método baseado na técnica de dispersão da matriz em fase sólida foi desenvolvido para determinar resíduos de ametrina, tetraconazol, flumetralina, tebuconazol, pirimetanil, diclofuanida e cresoxim-metílico na planta medicinal desidratada Hyptis pectinata (sambacaitá) por cromatografia a gás acoplada a espectrometria de massas. Diferentes parâmetros foram avaliados, tais como: tipo $\left(\mathrm{C}_{18}\right.$, alumina neutra, sílica gel e Florisil) e quantidades de sorvente e solvente de eluição (diclorometano, acetato de etila e diclorometano:acetato de etila $(1: 1, \mathrm{v} / \mathrm{v}))$, sendo que o mais adequado foi o procedimento com $0,5 \mathrm{~g}$ de planta medicinal, $0,5 \mathrm{~g}$ de $\mathrm{C}_{18}$ como sorvente $\mathrm{e}$ diclorometano $(20 \mathrm{~mL})$ como solvente de eluição. O método foi validado com amostras de planta medicinal fortificadas com agrotóxicos em diferentes níveis de concentração $\left(0,05-1,0 \mu \mathrm{g} \mathrm{g}^{-1}\right)$. Recuperações médias $(n=4)$ variaram de 83 a $127 \%$, com coeficientes de variação entre 4 e $15 \%$. Os limites de detecção (LOD) variaram entre 0,02 e $0,07 \mu \mathrm{g} \mathrm{g}^{-1}$, enquanto que os limites de quantificação (LOQ), entre 0,05 e $0,1 \mu \mathrm{g} \mathrm{g}^{-1}$.
\end{abstract}

A method was developed using matrix solid-phase dispersion (MSPD), together with gas chromatography coupled to mass spectrometry (GC-MS) for determination of ametryn, tetraconazole, flumetralin, tebuconazole, pyrimethanil, dichlofluanid and kresoxim-methyl in dehydrated Hyptis pectinata (sambacaitá) medicinal plant material. The evaluated parameters included the type and amount of sorbent $\left(\mathrm{C}_{18}\right.$, neutral alumina, silica gel and Florisil) and the nature of the eluent (dichloromethane, ethyl acetate and dichloromethane:ethyl acetate $(1: 1, \mathrm{v} / \mathrm{v}))$. The best results were obtained using $0.5 \mathrm{~g}$ of plant material, $0.5 \mathrm{~g}$ of $\mathrm{C}_{18}$ as sorbent and dichloromethane $(20 \mathrm{~mL})$ as the eluting solvent. The method was validated using plant samples spiked with pesticides at different concentration levels $\left(0.05-1.0 \mu \mathrm{g} \mathrm{g}^{-1}\right)$. Average recoveries (using four replicates) ranged from 83 to $127 \%$, with relative standard deviations between 4 and 15\%. Limits of detection (LOD) and quantification (LOQ) were in the ranges 0.02-0.07 $\mu \mathrm{g} \mathrm{g}^{-1}$ and $0.05-0.1 \mu \mathrm{g} \mathrm{g}^{-1}$, respectively.

Keywords: Hyptis pectinata, matrix solid-phase dispersion, medicinal plant, sambacaitá, pesticides

\section{Introduction}

Brazil possesses an extremely rich flora with about 55 thousand of known species. Amongst these, around 10 thousand may be considered to be medicinal and/or aromatic plants. ${ }^{1}$ In the Northeast region of Brazil, there is a high diversity of native plant species, which include plants belonging to the genus Hyptis, whose medicinal properties result in their common usage in traditional medicine. ${ }^{2}$ The genus Hyptis comprises around 400 species, distributed throughout the Americas, Western Africa,

*e-mail: sandnavi@ufs.br
Oceania and Western India. These plants have high socioeconomic importance since they are used for decoration and culinary purposes besides providing essential aromatic oils. ${ }^{3}$ The species Hyptis pectinata (L) Poit, belonging to the Lamiaceae family and locally known as "sambacaitá" or "canudinho", is used as a medicinal tea (infusion or decoction) for treating skin diseases, gastric disorders, nasopharyngitis, nasal congestion, fever and others infections caused by bacteria and fungi. ${ }^{4}$

Medicinal plants are liable to contain pesticide residues that may accumulate from agricultural practices, such as spraying, storage, transportation or soil treatment during cultivation. ${ }^{5}$ Besides, different products (like pyrimethanil, 
ametryn, dichlofluanid, tetraconazole, flumetralin, kresoxim-methyl and tebuconazole) are used to control phytophagous insects and fungal pathogens on a variety of crops in the Northeastern part of Brazil. The European Pharmacopoeia has proposed methods for analyses of pesticide residues in medicinal plants, establishing maximum residue limits (MRLs) for organochlorines, organophosphorus and pyrethroid pesticides. ${ }^{6}$

Various methods have been described for the determination of these pesticides, using solid-phase microextraction (SPME), ${ }^{7}$ solid-phase extraction (SPE), ${ }^{8,9}$ supercritical fluid extraction $(\mathrm{SFE})^{6}$ and matrix solid-phase dispersion (MSPD).$^{10}$ However, none of the published researches to date have reported the simultaneous analysis of chemical classes such as anilinopyrimidine, triazine, sulfonamide, dinitroaniline, strobilurin and triazole in Hyptis pectinata.

The matrix solid-phase dispersion (MSPD) technique was developed by Barker in 1989. It has advantages over conventional techniques because it employs small amounts of sample and solvent, and the extraction procedure consists of only a few experimental steps. MSPD evolved from the solid-phase extraction (SPE) technique, modified for application to solid and semi-solid matrices. ${ }^{11}$ The MSPD procedure is based on the use of a sorbent, which acts as an abrasive in order to produce a modified "opening" of the solid matrix, facilitating the extraction process when using a suitable solvent for eluting the analytes. ${ }^{12}$ The use of MSPD for pesticide recovery depends on the solubility of the pesticide in the eluting solvent, as well as the interactions between the matrix components, sorbent and eluent. ${ }^{13}$

Due to the lack of literature reports concerning the use of MSPD as an extraction technique for pesticides belonging to different chemical classes from medicinal plants (different plants and herbs exhibit different capabilities in retaining pesticide residues), this paper presents an MSPD method for determination of residues of pesticides in sambacaitá. So, the present research considered seven different chemical classes, namely anilinopyrimidine (pyrimethanil), triazine (ametryn), sulfonamide (dichlofluanid), triazine (tetraconazole), dinitroaniline (flumetralin), strobilurin (kresoxim-methyl) and triazole (tebuconazole), with analysis by gas chromatography-mass spectrometry (GC-MS).

\section{Experimental}

\section{Standards, reagents and supplies}

Certified standards of pyrimethanil, ametryn, dichlofluanid, tetraconazole, flumetralin, kresoxim-methyl and tebuconazole, at purities $>95 \%$, were purchased from AccuStandard (New Haven, CT, USA). Dichloromethane and ethyl acetate were pesticide grade (Tedia, Fairfield, $\mathrm{OH}, \mathrm{USA})$. Analytical grade anhydrous sodium sulfate was obtained from Mallinckrodt Baker (Paris, KY, USA), silica gel 60 (70-230 mesh) from Merck (Darmstadt, Germany), neutral alumina (70-290 mesh, activity I) from MachereyNagel (Düren, Germany) and $\mathrm{C}_{18}$-bonded silica $(50 \mu \mathrm{m})$ from Phenomenex (Torrance, CA, USA).

\section{Stock solutions}

The pesticide stock solutions were individually prepared in dichloromethane at a concentration level of $100 \mu \mathrm{g} \mathrm{mL}^{-1}$ and stored in a freezer at $-18{ }^{\circ} \mathrm{C}$. The stock standard solutions were used for up to 1 month. Suitable concentrations of working standards were prepared from the stock solutions by dilution using dichloromethane, immediately prior to sample preparation.

\section{Sample preparation}

Dehydrated sambacaitá samples were purchased in the municipal market of Aracaju, Sergipe State, Brazil. They were brought to the laboratory and stored in plastic bags at ambient temperature until they were processed. In the laboratory, samples were ground using a food processor and then stored in screw cap vials. Recovery experiments were performed using $0.5 \mathrm{~g}$ portions of sambacaitá spiked with $500 \mu \mathrm{L}$ of working solution, resulting in concentrations of $0.05,0.1,0.5$ and $1.0 \mu \mathrm{g} \mathrm{g}^{-1}$. The spiked samples were allowed to rest for $30 \mathrm{~min}$ to aid solvent evaporation and interaction between analytes and sample matrix. Four replicates were analyzed at each fortification level.

\section{Extraction procedure}

$0.5 \mathrm{~g}$ of sambacaitá was weighed out and homogenized with $0.5 \mathrm{~g}$ of $\mathrm{C}_{18}$-bonded silica for $3 \mathrm{~min}$. The homogenized sample was transferred to an MSPD column consisting of a $20 \mathrm{~mL}$ capacity polyethylene syringe containing silanized glass wool (as a support base) and $1.0 \mathrm{~g}$ of anhydrous sodium sulfate. The elution was performed under vacuum with $20 \mathrm{~mL}$ of dichloromethane. The eluent was collected into a graduated conical tube, concentrated using a rotary vacuum evaporator (at $45^{\circ} \mathrm{C}$ ) and finally purged with a gentle stream of nitrogen to a volume of $1 \mathrm{~mL}$. An aliquot of $1 \mu \mathrm{L}$ was analyzed by GC-MS.

\section{Apparatus}

A Shimadzu system (Kyoto, Japan), consisting of a GC 2010 gas chromatograph with a split/splitless injector, 
coupled to a QP-2010Plus mass spectrometer, was used for the identification and quantification of the pesticides. A fused silica RTx-5MS column (5\% phenyl-95\% polydimethylsiloxane, $30 \mathrm{~m} \times 0.25 \mathrm{~mm}$ ID, $0.25 \mu \mathrm{m}$ film thickness), supplied by Restek (Bellefonte, PA, USA), was employed, with helium (purity 99.995\%) as carrier gas at a flow rate of $1.2 \mathrm{~mL} \mathrm{~min}^{-1}$. The $\mathrm{GC}$ oven temperature was programmed from $60{ }^{\circ} \mathrm{C}(1 \mathrm{~min})$ to $290{ }^{\circ} \mathrm{C}(3 \mathrm{~min})$ at $10{ }^{\circ} \mathrm{C} \mathrm{min}-1$. The solvent delay was $5 \mathrm{~min}$. The injector port was maintained at $250{ }^{\circ} \mathrm{C}$, and $1 \mu \mathrm{L}$ sample volumes were injected in splitless mode (50 s). The eluent from the GC column was transferred via a transfer line heated at $280{ }^{\circ} \mathrm{C}$, and fed into a $70 \mathrm{eV}$ electron ionization source, also maintained at $280{ }^{\circ} \mathrm{C}$. The MS was tuned to $\mathrm{m} / \mathrm{z} 69$, 219 and 512 with perfluorobutylamine (PFTBA). The data were acquired and processed using Shimadzu GC Solution software. The total analysis time was $27 \mathrm{~min}$.

\section{Method validation}

Method validation ensures analysis credibility. In this study, the parameters accuracy, precision, linearity and limits of detection (LOD) and quantification (LOQ) were considered. ${ }^{14}$ The accuracy of the method was determined by recovery tests, using samples spiked at concentration levels of $0.05,0.1,0.5$ and $1.0 \mu \mathrm{g} \mathrm{g}^{-1}$. Linearity was assessed (in triplicate) by preparation of analytical curves using analytical standards prepared in blank matrix extract at concentration levels of $0.1,0.25,0.5,5.0$ and $7.0 \mu \mathrm{g} \mathrm{mL} \mathrm{mL}^{-1}$. The limits of detection were calculated considering the standard deviation of the noise (a value of 7 times the standard deviation of the blank) and the slope of the regression line. The limits of quantification were determined as the concentration giving a response of ten times the average of the baseline noise obtained from seven unfortified samples. ${ }^{15}$

\section{Results and Discussion}

\section{Chromatographic conditions}

The retention times of the pesticides were measured using individual standard solutions at concentrations of $5.0 \mu \mathrm{g} \mathrm{mL}^{-1}$. The GC-MS instrument was operated in full scan mode, varying the oven temperature and the carrier gas flow rate. The most representative (most intense) ions were selected for quantification of the pesticides in the sambacaitá samples. The analysis was performed in the selected ion monitoring (SIM) mode. For the first acquisition window (5.0 to $17.5 \mathrm{~min}$ ), the ions monitored were $\mathrm{m} / z, 183,198$ and 199 (pyrimethanil, $16.9 \mathrm{~min}$ ).
For the second acquisition window (17.5 to $19.5 \mathrm{~min}$ ) $\mathrm{m} / \mathrm{z}, 185,212$ and 227 (ametryn, $18.1 \mathrm{~min}$ ), $\mathrm{m} / \mathrm{z} 123,167$ and 224 (dichlofluanid, $18.6 \mathrm{~min}$ ), $\mathrm{m} / \mathrm{z}$ 171, 336 and 338 (tetraconazole, $18.9 \mathrm{~min}$ ) were monitored. For the third acquisition window (19.5 to $27.0 \mathrm{~min}$ ), $\mathrm{m} / \mathrm{z} .145,157$ and 404 (flumetralin, $20.3 \mathrm{~min}$ ), $\mathrm{m} / \mathrm{z}, 131,206$ and 282 (kresoxim-methyl, $20.9 \mathrm{~min}$ ) and $\mathrm{m} / \mathrm{z}, 125,250$ and $\mathbf{2 5 2}$ (tebuconazole, $22.8 \mathrm{~min}$ ) were monitored. Values of $\mathrm{m} / \mathrm{z}$ in bold type correspond to the quantification ion used for each analyte.

Chromatograms obtained after MSPD for a typical sambacaitá extract spiked at a mixed $1.0 \mu \mathrm{g} \mathrm{g}^{-1}$ standard solution, and for a mixed standard solution in a blank sambacaitá sample extract at the same concentration level are illustrated in Figure 1, together with a chromatogram of the sambacaitá control sample. The chromatographic profile demonstrates the selectivity of the technique, and show the importance of selecting a suitable sorbent and eluting solvent in order to minimize matrix interferences.

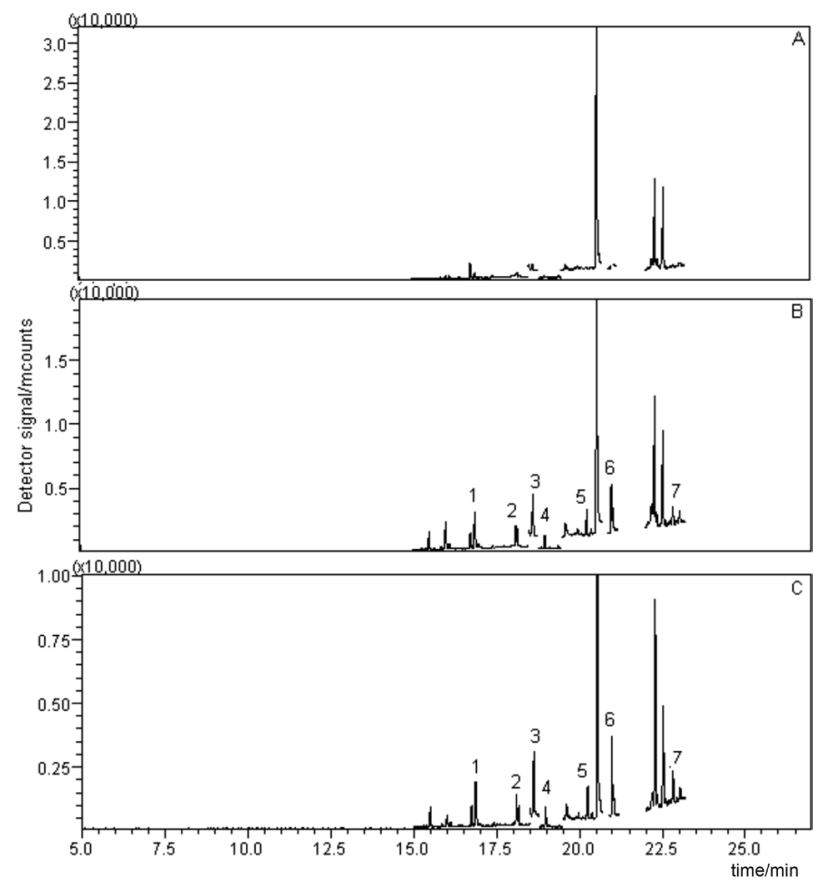

Figure 1. GC-MS (SIM mode) chromatograms of (A) a sambacaitá control sample, (B) a mixed standard solution at a concentration level of $1.0 \mu \mathrm{g} \mathrm{g}^{-1}$ using $0.5 \mathrm{~g}$ of sambacaitá with $0.5 \mathrm{~g}$ of $\mathrm{C}_{18}$-bonded silica and $20 \mathrm{~mL}$ of dichloromethane, (C) a typical sambacaitá extract spiked at a concentration level of $1.0 \mu \mathrm{g} \mathrm{g}^{-1}$. The numbered peaks are as follows: 1-pyrimethanil, 2-ametryn, 3-dichlofluanid, 4-tetraconazole, 5-flumetralin, 6-kresoxim-methyl and 7-tebuconazole.

\section{Matrix effect}

A shift in the signal intensity was observed due to the influence of the matrix components. This effect was assessed by comparing the values of the instrumental 
Table 1. Influence of different sorbents on pesticide recoveries using dichloromethane as eluting solvent during the MSPD procedure. Sambacaitá sample spiked at $1.0 \mu \mathrm{g} \mathrm{g} \mathrm{g}^{-1}$

\begin{tabular}{|c|c|c|c|c|}
\hline \multirow{3}{*}{ Pesticide } & \multicolumn{4}{|c|}{$\begin{array}{c}\text { Average recovery / \% } \\
\text { Dichloromethane }(20 \mathrm{~mL})\end{array}$} \\
\hline & Silica gel & $\mathrm{C}_{18}$-bonded silica & Florisil & Neutral alumina \\
\hline & \multicolumn{4}{|c|}{$0.5 \mathrm{~g}$} \\
\hline Pyrimethanil & 83 & 97 & 86 & 133 \\
\hline Ametryn & 71 & 85 & 64 & 100 \\
\hline Dichlofluanid & 109 & 91 & 116 & 79 \\
\hline Tetraconazole & 60 & 100 & 72 & 102 \\
\hline Flumetralin & 76 & 130 & 99 & 104 \\
\hline Kresoxim-methyl & 85 & 95 & 89 & 91 \\
\hline Tebuconazole & 29 & 111 & 34 & 97 \\
\hline
\end{tabular}

${ }^{a}$ Each sample was extracted 2 times and each extract was analyzed 2 times $(n=4)$.

responses (chromatographic peak areas) for the pesticide solutions with those of solutions prepared in the sample extract at the same concentrations. For all pesticides, the area values were found to be higher for the sample extracts. Since the matrix effect was significant, matrix-matched calibration standards were used to compensate the signal enhancement of the pesticides in matrix solutions compared to their responses in pure solvent.

\section{MSPD extraction procedure}

In MSPD, selection of a suitable sorbent/solvent system is determined by the polarity of the analyte and the nature of the matrix. The isolation of polar analytes is achieved using polar sorbents, while the isolation of non-polar analytes requires non-polar sorbents. ${ }^{16}$

Here, preliminary tests were performed to evaluate the efficiency of the pesticide extractions from the sample matrix, using dichloromethane with silica gel, Florisil, neutral alumina and $\mathrm{C}_{18}$-bonded silica as sorbents. The recoveries of the pesticides in the extracts were calculated by peak area comparisons using solutions of known concentration. Table 1 provides the percentage recoveries obtained for the different MSPD sorbent/solvent systems.

\section{Type of sorbent}

The results showed that the normal phase sorbents (silica gel, Florisil and neutral alumina) only interacted with the sample components by adsorption. ${ }^{16}$ At the spiked level of $1.0 \mu \mathrm{g} \mathrm{g}^{-1}$, recovery values using Florisil and silica gel with dichloromethane elution were below the range reported in the literature $(70-130 \%)$ for tetraconazole $(60 \%$ for silica gel), tebuconazole (29 and 34\% for silica gel and Florisil, respectively) and ametryn (64\% for Florisil). ${ }^{17}$ The use of neutral alumina provided recovery values of $79-133 \%$ for the studied pesticides. When using $\mathrm{C}_{18}$-bonded silica as sorbent, there is no desorption and/or adsorption of the compounds, since separation on a chemically-bonded phase $\left(\mathrm{C}_{18}\right)$ occurs by partition. ${ }^{18}$ The recovery values using $\mathrm{C}_{18}$-bonded silica were in the range $83-130 \%$, showing that this was the most effective sorbent for extraction of the pesticides.

\section{Amount of sorbent}

Since the relative amounts of sorbent and sample could influence recoveries, two different quantities of sorbent $(0.5$ and $1.0 \mathrm{~g}$ ) were tested (Table 2). No significant difference was observed, so that $0.5 \mathrm{~g}$ of sorbent was therefore chosen for use during the recovery experiments.

Table 2. Influence of sorbent amount on pesticide recovery. Sambacaitá sample spiked at $1.0 \mu \mathrm{g} \mathrm{g}^{-1}$

\begin{tabular}{lcc}
\hline & \multicolumn{2}{c}{$\begin{array}{c}\text { Average recovery / \% } \\
\text { Dichloromethane }(20 \mathrm{~mL})\end{array}$} \\
\cline { 2 - 3 } Pesticide & \multicolumn{2}{c}{$\mathrm{C}_{18}$-bonded silica / g } \\
\cline { 2 - 3 } & 0.5 & 1.0 \\
\hline Pyrimethanil & 90 & 97 \\
Ametryn & 89 & 85 \\
Dichlofluanid & 92 & 91 \\
Tetraconazole & 100 & 100 \\
Flumetralin & 124 & 130 \\
Kresoxim-methyl & 89 & 95 \\
Tebuconazole & 83 & 111 \\
\hline${ }^{a}$ Each sample was extracted 2 times and each extract was analysed 2 \\
times (n=4).
\end{tabular}

\section{Type of eluent}

The influence of the elution solvent was evaluated, using $\mathrm{C}_{18}$-bonded silica as sorbent and $20 \mathrm{~mL}$ of the following 
solvents: dichloromethane, dichloromethane:ethyl acetate $(1: 1, \mathrm{v} / \mathrm{v})$ and ethyl acetate. There were only minor differences in the recovery values, which remained in the range of $70-130 \%$ for all of the pesticides (Table 3). Although the uses of the different eluting solvents, similar recoveries were produced, dichloromethane was considered optimal for the extraction because it gave cleaner extracts. Therefore, dichloromethane was the choice of elution solvent.

Table 3. Influence of eluting solvent on recovery, using $\mathrm{C}_{18}$-bonded silica as sorbent in the MSPD procedure, with $0.5 \mathrm{~g}$ of sambacaitá and $0.5 \mathrm{~g}$ of $\mathrm{C}_{18}$-bonded silica. Sambacaitá sample spiked at $1.0 \mu \mathrm{g} \mathrm{g}^{-1}$

\begin{tabular}{lccc}
\hline & \multicolumn{3}{c}{$\begin{array}{c}\text { Average recovery / \% } \\
\text { Cesticides }\end{array}$} \\
\cline { 2 - 4 } & \multicolumn{3}{c}{-bonded silica (0.5 g) } \\
\cline { 2 - 4 } & DCM $^{\mathrm{b}}$ & DCM:ethyl acetate (1:1) & Ethyl acetate \\
\hline Pyrimethanil & 90 & 86 & 84 \\
Ametryn & 89 & 89 & 83 \\
Dichlofluanid & 92 & 88 & 94 \\
Tetraconazole & 100 & 105 & 94 \\
Flumetralin & 124 & 114 & 104 \\
Kresoxim-methyl & 89 & 106 & 94 \\
Tebuconazole & 83 & 105 & 102 \\
\hline
\end{tabular}

${ }^{a}$ Each sample was extracted 2 times and each extract was analysed 2 times $(\mathrm{n}=4)$; ${ }^{\text {DCM}}$ : dichloromethane.

\section{Method validation}

After optimization of the MSPD procedure, the technique was validated in order to demonstrate its reliability. ${ }^{14}$ The maximum residue levels (MRLs) of target compounds must always be taken into account when performing recovery studies. Since there are no specific regulations and parameters for herbal drugs in Brazil, the procedure adopted in this study was based on the developed work for Passiflora spp. study by Zuin et al., ${ }^{6}$ in which the MRLs established by the European Pharmacopoeia were 0.05 (dieldrin), 0.6 (lindane), 1.0 (malathion) and $1.8 \mu \mathrm{g} \mathrm{g}^{-1}$ (tetradifon).
Table 4. Percentage recoveries and relative standard deviations obtained for the pesticides studied using the MSPD procedure applied to the spiked sambacaitá medicinal plant material

\begin{tabular}{|c|c|c|}
\hline Pesticides & $\begin{array}{l}\text { Fortification level / } \\
\qquad\left(\mu \mathrm{g} \mathrm{g}^{-1}\right)\end{array}$ & $\begin{array}{c}\text { Average recovery } / \% \\
( \pm \% \text { RSD })\end{array}$ \\
\hline Pyrimethanil & $\begin{array}{c}0.05 \\
0.1 \\
1.0\end{array}$ & $\begin{array}{c}83 \pm 9 \\
108 \pm 7 \\
92 \pm 8\end{array}$ \\
\hline Ametryn & $\begin{array}{l}0.1 \\
0.5 \\
1.0\end{array}$ & $\begin{array}{c}90 \pm 15 \\
104 \pm 9 \\
91 \pm 8\end{array}$ \\
\hline Dichlofluanid & $\begin{array}{c}0.05 \\
0.1 \\
1.0\end{array}$ & $\begin{array}{c}127 \pm 15 \\
105 \pm 11 \\
99 \pm 12\end{array}$ \\
\hline Tetraconazole & $\begin{array}{l}0.1 \\
0.5 \\
1.0\end{array}$ & $\begin{array}{c}88 \pm 9 \\
105 \pm 11 \\
99 \pm 11\end{array}$ \\
\hline Flumetralin & $\begin{array}{l}0.1 \\
0.5 \\
1.0\end{array}$ & $\begin{array}{l}110 \pm 6 \\
113 \pm 6 \\
101 \pm 5\end{array}$ \\
\hline Kresoxim-methyl & $\begin{array}{l}0.1 \\
0.5 \\
1.0\end{array}$ & $\begin{array}{c}97 \pm 14 \\
99 \pm 10 \\
90 \pm 4\end{array}$ \\
\hline Tebuconazole & $\begin{array}{l}0.1 \\
0.5 \\
1.0\end{array}$ & $\begin{array}{l}96 \pm 4 \\
85 \pm 8 \\
88 \pm 8\end{array}$ \\
\hline
\end{tabular}

$\overline{{ }^{a} E a c h ~ s a m p l e ~ w a s ~ e x t r a c t e d ~} 4$ times and each extract was analysed 2 times $(n=8)$.

The concentration levels evaluated in this study were 0.05 , $0.1,0.5$ and $1.0 \mu \mathrm{g} \mathrm{g}^{-1}$, consistent with the concentrations values used by Zuin et al. ${ }^{6}$ The recovery values obtained for pyrimethanil, ametryn, dichlofluanid, tetraconazole, flumetralin, kresoxim-methyl and tebuconazole ranged from 83 to $127 \%$ when using concentration levels of 0.1 , 0.1 and $1 \mu \mathrm{g} \mathrm{g}^{-1}$, with relative standard deviations between 4 and $15 \%$ (Table 4). These values indicate that the method is accurate and precise for the quantification of pesticide residues in sambacaitá.

Linearity was calculated from the analytical curves obtained using sambacaitá sample solutions with pesticide concentrations of $0.1,0.25,0.5,5.0$ and $7.0 \mu \mathrm{g} \mathrm{mL}^{-1}$, in triplicate analysis (Table 5). Good linearity was obtained for all pesticides with coefficients of determination greater

Table 5. Calibration data, limits of detection and quantification for the pesticides analyzed by GC-MS

\begin{tabular}{llcccc}
\hline Pesticide & Equation & $\mathrm{r}$ & Concentration range $/\left(\mu \mathrm{gL}^{-1}\right)$ & $\left.\mathrm{LOD} /(\mu \mathrm{g} \mathrm{g})^{-1}\right)$ & $\left.\mathrm{LOQ} /(\mu \mathrm{g} \mathrm{g})^{-1}\right)$ \\
\hline Pyrimethanil & $\mathrm{y}=31725.6 \mathrm{x}+1320.89$ & 0.9992 & $0.1-7.0$ & 0.02 & 0.05 \\
Ametryn & $\mathrm{y}=8934.9 \mathrm{x}+803.29$ & 0.9989 & $0.1-7.0$ & 0.05 & 0.1 \\
Dichlofluanid & $\mathrm{y}=24948.2 \mathrm{x}-739.83$ & 0.9998 & $0.1-7.0$ & 0.02 & 0.05 \\
Tetraconazole & $\mathrm{y}=10605.6 \mathrm{x}+859.12$ & 0.9987 & $01-7.0$ & 0.05 & 0.1 \\
Flumetralin & $\mathrm{y}=12144.7 \mathrm{x}-401.82$ & 0.9998 & $0.1-7.0$ & 0.07 & 0.1 \\
Kresoxim-methyl & $\mathrm{y}=23917.4 \mathrm{x}+1472.36$ & 0.9992 & $0.1-7.0$ & 0.07 & 0.1 \\
Tebuconazole & $\mathrm{y}=11574.3 \mathrm{x}+830.35$ & 0.9990 & $0.1-7.0$ & 0.1 \\
\hline
\end{tabular}


than 0.9987. Limits of detection and quantification from 0.02 to $0.07 \mu \mathrm{g} \mathrm{g}^{-1}$ and from 0.05 to $1.0 \mu \mathrm{g} \mathrm{g}^{-1}$, respectively. ${ }^{14}$

\section{Method application}

The method developed was used to analyze samples of sambacaitá purchased in the municipal market of Aracaju (Sergipe State, Brazil). No pesticides were detected in any of the samples analyzed.

\section{Conclusions}

The proposed MSPD method, with analysis by GC-MS in SIM mode, has been shown to be efficient for the extraction of pyrimethanil, ametryn, dichlofluanid tetraconazole, flumetralin, kresoxim-methyl and tebuconazole residues from sambacaitá medicinal plant material. Recovery values and precisions were comparable to previously published data, as well as for limits of detection and quantification and linearity. The MSPD technique is simple, fast, efficient and low cost. No pesticide residues were detected in samples of sambacaitá purchased in a local marketplace.

\section{Acknowledgments}

The authors wish to thank Ministério da Ciência e Tecnologia/Conselho Nacional de Desenvolvimento Científico e Tecnológico (MCT/CNPq) (process No. 620247/2008-8) for financial support of this study. A. A. also thanks Coordenação de Aperfeiçoamento de Pessoal de Nível Superior (CAPES) for provision of a research fellowship.

\section{References}

1. Silva, R. L.; Melo G. B.; Antoniolli, A. R.; Lima S. O.; Melo V. A.; Ramalho F. S.; Ramalho, L. N. Z.; Zucoloto, S.; Castro O.; Júnior, S.; Acta Cir. Bras. 2002, 17, 101.
2. Arrigoni-Blank, M. F.; Antoniolli, A. R.; Caetano, L. C.; Campos, A. D.; Blank, A. F.; Alves, P. B.; Phytomedicine 2008, $15,334$.

3. Santos, P. O.; Costa, M. J. C.; Alves, J. A. B.; Nascimento, P. F. C.; Melo, D. L. F. M.; Barbosa, J. R. A. M.; Trindade, R. C.; Quim. Nova 2008, 31, 1648.

4. Nascimento, P. F. C.; Alviano, W. S.; Nascimento, A. L. C.; Santos, P. O.; Blank, M. F. A.; Jesus, R. A.; Azevedo, V. G.; Alviano, D. S.; Bolognese, A. M.; Trindade, R. C.; Oral Diseases 2008, 14, 485.

5. Chang, K.; Chemosphere 2003, 52, 1361.

6. Zuin, V. G.; Yariwake, J. H.; Lanças, F. M.; J. Braz. Chem. Soc. 2003, 14, 304.

7. Ho, W.; Hsieh, S. J.; Anal. Chim. Acta 2001, 428, 111.

8. Qing, G.; Xia, L.; Bo-Yang, Y.; J. Nat. Med. 2009, 7, 210.

9. Nguyen, T. D.; Lee, K. J.; Lee, M. H.; Lee, G. H.; Microchem. J. 2010, 95, 43.

10. Abhilash, P. C.; Singh, V.; Singh, N.; Food Chem. 2009, 113, 267.

11. Barker, S. A.; J. Biochem. Biophys. Methods 2007, 70, 151.

12. Dawidowicz, A. L.; Rado, E.; J. Pharm. Biomed. Anal. 2010, 52,79 .

13. Capriotti, A. L.; Cavaliere, C.; Giansanti, P.; Gubbiotti, R.; J. Chromatogr., A 2010, 1217, 2521.

14. Bliesner, D. M.; Validating Chromatographic Methods-A Practical Guide, John Wiley \& Sons Publications: New Jersey, 2006.

15. SANCO No. 10232/2006; Quality Control Procedures for Pesticide Residues Analysis, The European Commission: United Kingdom, 2006.

16. Garcia-Lopes, M.; Canosa, P.; Rodrígues, J.; Anal. Bioanal. Chem. 2008, 391, 963.

17. Maffei, D. F.; Nogueira, A. R. A.; Brondi, S. H. G.; Quim. Nova 2009, 32, 1713.

18. Bogialli, S.; Di Corcia, A.; J. Biochem. Biophys. Methods 2007, $70,163$.

Submitted: July 28, 2010

Published online: May 5, 2011 